\title{
QUEEN'S
UNIVERSITY
BELFAST
}

\section{Ionic Liquid Microcapsules: Formation and Application of Polystyrene Microcapsules with lonic Liquid Cores}

Lobato Guarnido, I., Routh, A. F., Mantle, M. D., Fernandez Serrano, M., \& Marr, P. C. (2019). Ionic Liquid Microcapsules: Formation and Application of Polystyrene Microcapsules with lonic Liquid Cores. ACS

Sustainable Chemistry \& Engineering. https://doi.org/10.1021/acssuschemeng.8b05478

Published in:

ACS Sustainable Chemistry \& Engineering

Document Version:

Peer reviewed version

Queen's University Belfast - Research Portal:

Link to publication record in Queen's University Belfast Research Portal

Publisher rights

(c) 2019 American Chemical Society. This work is made available online in accordance with the publisher's policies. Please refer to any applicable terms of use of the publisher.

\section{General rights}

Copyright for the publications made accessible via the Queen's University Belfast Research Portal is retained by the author(s) and / or other copyright owners and it is a condition of accessing these publications that users recognise and abide by the legal requirements associated with these rights.

Take down policy

The Research Portal is Queen's institutional repository that provides access to Queen's research output. Every effort has been made to ensure that content in the Research Portal does not infringe any person's rights, or applicable UK laws. If you discover content in the Research Portal that you believe breaches copyright or violates any law, please contact openaccess@qub.ac.uk. 


\title{
Ionic Liquid Microcapsules: Formation and Application of Polystyrene Microcapsules with Ionic Liquid Cores.
}

\author{
Ismael Lobato Guarnido ${ }^{d}$ Alexander F. Routh ${ }^{c}$ Michael D. Mantle ${ }^{c}$ Mercedes Fernandez \\ Serrano ${ }^{d}$ and Patricia C. Marr* a,b
}

a) School of Chemistry and Chemical Engineering, The Queen's University of Belfast, The David Keir Building, Stranmillis road, Belfast. BT9 5AG, UK. p.marr@qub.ac.uk

b) QUILL, School of Chemistry and Chemical Engineering, The Queen's University of Belfast, The David Keir Building, Stranmillis road, Belfast. BT9 5AG, UK. BT9 5AG, UK. p.marr@qub.ac.uk

c) Department of Chemical Engineering and Biotechnology, University of Cambridge, Philippa Fawcett Drive, Cambridge, CB3 OAS, UK.

d) Department of Chemical Engineering, Faculty of Sciences, University of Granada, Campus Fuentenueva s/n, 18071 Granada, Spain.

\begin{abstract}
The synthesis of 2-3 $\mu \mathrm{m}$ spherical microcapsules with a polymer shell and a liquid core comprised of ionic liquid (IL) ([Bmim][NTf2]) is described. These discrete IL microcapsules are prepared quickly and in large quantity in a low temperature, one pot synthesis, by a modified coacervation technique. These IL microcapsules show ability to release dye from the IL core into solution through a polymer membrane and also concentrate metal ions from solution into the microcapsules.
\end{abstract}

\section{Keywords}

Core-shell, ionic liquid materials, dye release, extraction, polymer membrane.

\section{INTRODUCTION}

We present spherical microcapsules of polystyrene containing ionic liquid in their core. Materials such as these have many potential uses in sustainable applications. Ionic liquids, (ILs) are liquids composed entirely of ions. ${ }^{1,2,3}$ They have a remarkable ability to be tuned for specific application, providing new approaches in science, technology and industry. Since their early use as replacements for organic solvents, ${ }^{4}$ uses of lonic liquids continue to expand. In particular, there has been a lot of recent interest in ionic liquids and ionic liquid materials in energy and electronics. ${ }^{5,6,7}$ Catalysis continues to feature heavily as an area which has seen benefit from ionic liquids ${ }^{8}$ as does environmental remediation such as $\mathrm{CO}_{2}$ uptake, ${ }^{9}$ energy materials ${ }^{10}$ and metal recovery. ${ }^{11}$ Steady interest and new applications are coming from the pharmaceutical, drug delivery and medicinal areas ${ }^{10,12,13,14}$ as well as the food industry. ${ }^{15}$ In the pharmaceutical fine chemicals sector, the use of ionic liquids in drug ${ }^{16}$ and fragrance delivery ${ }^{17}$ has been noted. Ionic liquids are being used as drugs themselves. Davis and co-workers ${ }^{18}$ 
synthesised an alkylated derivative of miconazole (an antifungal drug), which was combined with $\left[\mathrm{PF}_{6}\right]^{-}$to form the ionic liquid, alkylmiconazolium hexafluorophosphate. The same group reported formation of ILs from artificial sweeteners combining the anions of saccharin and acesulfame with organic cations. ${ }^{13}$ Ionic liquids as drugs are seen to have many potential benefits. ${ }^{19,20}$ Most recently an oral delivery method for insulin featuring an ionic liquid made from choline and geranic acid (CAGE), ${ }^{21}$ which has shown to be effective in protein stabilisation over long periods. Previous work using CAGE showed stabilisation of protein drugs for transdermal delivery. ${ }^{22}$ However, there are some drawbacks to the large scale use of ionic liquids. These include separation issues, fear of possible release of material to the environment, loss of liquid electrolyte from electronic devices and contamination of products in reactions. Finding ways to circumvent these issues using materials synthesis is an important goal. In particular lonic liquid gel ${ }^{23}$ : sol-gel, polymer, and low molecular weight ionic liquid gels ${ }^{24,25}$ continue to play a role. supported ionic liquid acids, ${ }^{26}$ bases ${ }^{27}$ and entrapped catalysts ${ }^{28}$ are facilitating the use of catalysts with easy separation. Confining ionic liquids can broaden their application further and also help to build theoretical models of IL behavior. ${ }^{29,30}$ Whether for use in catalysis or environmental clean-up, lonic liquids containing actives of high value need to be easily separated for recycling. Extraction of active products or recovery of metals into ionic liquids currently requires large scale separations. Using ionic liquids for extractions ${ }^{31,32}$ could be easily enhanced by using a suitable membrane technology. Confinement of ionic liquids within a membrane would facilitate their use in a wide range of industrial and academic disciplines. The use of ionic liquid membranes shows promise in many applications ${ }^{33}$ but the encapsulation or confinement has yet to be achieved easily in 3 dimensions. Examples of spherical encapsulated ionic liquids are rare. Previous attempts to produce ionic liquids confined within polymer shells include individual coating of spherical IL drops with a polymer ${ }^{34}$ and formation of microgels, ${ }^{35}$ both of these methods have limitations for large scale production. Encapsulation is the process by which a

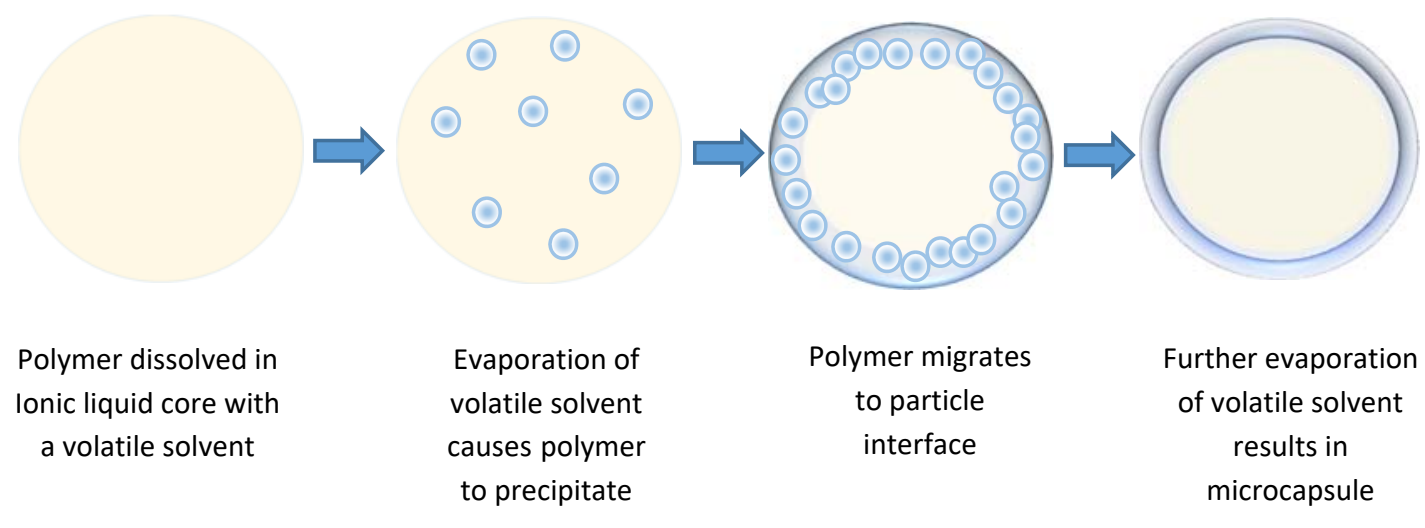


material is contained within a shell of a second material. ${ }^{36}$ Liquid core microcapsules are used for a variety of purposes from flavor protection in food to delayed release of pharmaceuticals. ${ }^{37}$ Release from microcapsules can be achieved by a number of mechanisms. For hard rigid shells, such as metals or inorganics a brittle fracture, due to shear ${ }^{38}$ or ultrasound ${ }^{39}$ can be achieved. For polymeric shells a slow diffusional release profile is more common. ${ }^{40}$ There are many possible routes to making microcapsules. These include direct polymerization from a surface ${ }^{41}$ layer by layer deposition $42,43,44,45$ or self-assembly of particles at a templating interface. ${ }^{46,47,48,49}$

\section{EXPERIMENTAL}

We have prepared spherical microcapsules of polystyrene containing ionic liquid in their core. This is achieved at low temperature in one pot with a resultant large quantity of spheres. The basis of the method used in this work is adapted from the work of Loxley and Vincent ${ }^{50}$ and shown schematically (Figure. 1) In the original method the polymer shell material is insoluble in the core, which contains a low volatility organic solvent. The two components are mixed with a volatile solvent, typically dichloromethane, forming a single organic phase. This is emulsified in water, containing a small amount of surfactant. The resulting emulsion droplets are templates for the microcapsules. As the volatile solvent evaporates the polymer precipitates and, depending on the wetting conditions,

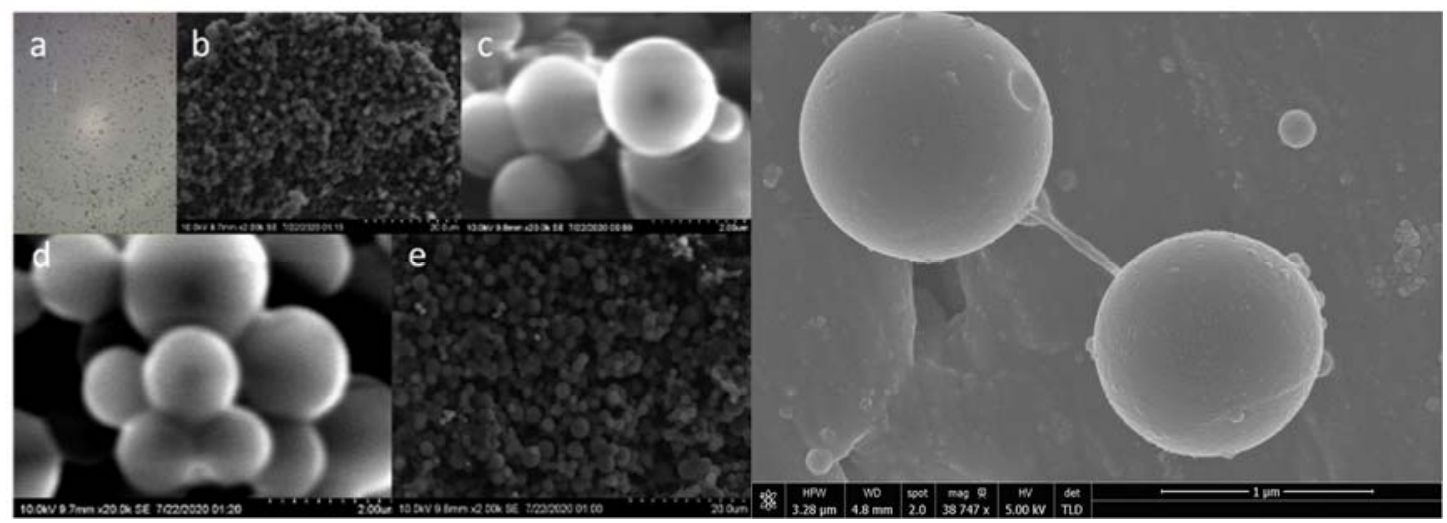

Figure 2 Microscopy images of microcapsules with an ionic liquid core and polystyrene shell. (a) Optical microscopy shows a large yield Figure 2 Microscopy images of microcapsules with an ionic liquid core and polystyrene shell. (a) Optical microscopy shows a large yield
of capsules (b) and (e) low magnification SEM images show a large number of capsules. (c) and (d) high magnification SEM show the spherical nature of the shell. (f) SEM image shows smooth structure of polymer shells.

forms a shell surrounding the organic core. We postulated that it may be possible to replace the low volatility organic phase with an ionic liquid. Thus forming microcapsules of ionic liquid contained in a polystyrene shell. This proved to be successful (SI S1.2 Methods).

\section{RESULTS AND DISCUSSION}

Initial studies on dye release from the ionic liquid core through the polystyrene membrane, and metal uptake through the polystyrene membrane into the ionic liquid core were performed. The microscopy images (Figure. 2) and (SI S5.0) show that we have successfully produced ionic liquid 
core microcapsules. These are easily made in the liter scale. The capsules have a size of a few

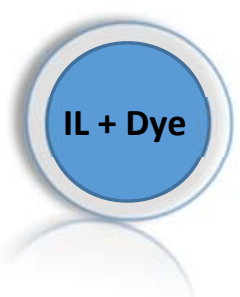

a

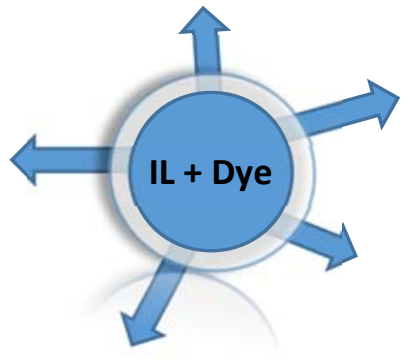

b

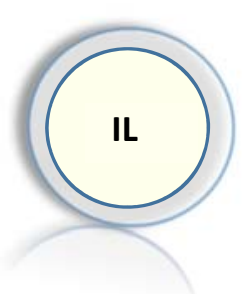

c

Figure 3 Schematic of dye release experiments with ionic liquid core microcapsules a) thymol blue Dye +IL. b) diffusion of dye through polymer shell. c) remaining IL in core after dye diffusion.

microns $(\sim 2 \mu \mathrm{m})$. This is set by the emulsification technique. Smaller capsules can be achieved, for example with vigorous emulsification or the use of ultrasound. The shell thickness is simply determined by the concentration of polymer solution. The release of dye from the capsules (Figure. 3) follows the expected trend, with more polymer in the shell resulting in slower release. The timescale for release is given by the inverse of the rate constant, which is calculated from the graph (Figure. 4).

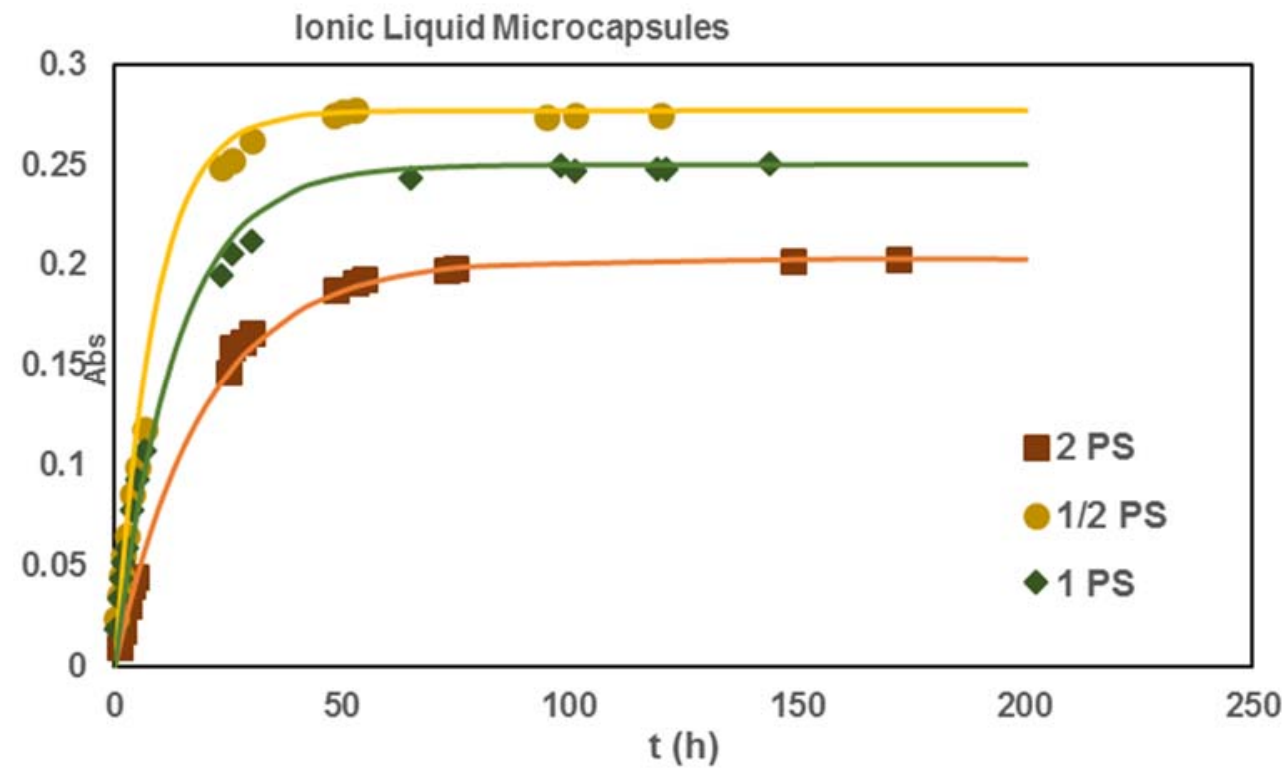

Figure 4 Dye release experiments. Release of thymol blue from lonic liquid core microcapsules through different polystyrene shell thickness.

The numerical values are shown in the $\mathrm{SI}$, (SI, S6 Dye release, table S1). We assume that all dye is partitioned into the core and that release follows a diffusional timescale, $\tau$, such that $\tau=T^{2} / D$, with $T$ the shell thickness and $D$ the diffusion coefficient of dye through the solvated polymer. We derived a simple model to estimate this timescale. The total number of capsules is $N$ and the volume of the core is $4 / 3 \pi R^{3}$. We therefore have 
$N V_{\text {core }}=\frac{m_{I L}}{\rho_{I L}}=N \frac{4 \pi}{3} R^{3}$

With $m_{\mathrm{LL}}$ the mass of ionic liquid added to the mixture and $\rho_{\mathrm{IL}}$ the ionic liquid density. The volume of the shell, $V_{\text {shell, }}$ is given by

$$
N V_{\text {shell }}=\frac{m_{p}}{\rho_{p}}
$$

with $m_{p}$ the total mass of polymer and $\rho_{p}$ the polymer density. The overall volume balance provides

$$
V_{\text {core }}+V_{\text {shell }}=\frac{4 \pi}{3}(R+T)^{3}
$$

then

$$
\left(\frac{m_{p}}{\rho_{p}}+\frac{m_{L L}}{\rho_{I L}}\right)^{1 / 3}=\left(\frac{4 \pi N}{3}\right)^{1 / 3}(D \tau)^{1 / 2}+\left(\frac{m_{I L}}{\rho_{I L}}\right)^{1 / 3}
$$

In this work $m_{\mathrm{LL}}$ is $3.869 \mathrm{~g}$ and $\rho_{\mathrm{IL}}$ is $1437 \mathrm{~kg} / \mathrm{m}^{3}$. The polymer density $\rho_{\mathrm{p}}$ is taken as $1050 \mathrm{~kg} / \mathrm{m}^{3}$. This provides $\mathrm{m}_{\mathrm{L}} / \rho_{\mathrm{IL}}$ as $2.69 \times 10^{-6} \mathrm{~m}^{3}$. Plotting $\left(\mathrm{m}_{\mathrm{p}} / 1050+2.69 \times 10^{-6}\right)^{1 / 3}$ versus $\tau^{1 / 2}$ then produces a straight line as shown in (SI Figure S5) The slope of the best fit line is $1.63 \times 10^{-5} \mathrm{~m} \mathrm{~s}^{-1 / 2}$ and the intercept is given by $0.014 \mathrm{~m}$. Estimating the radius of the capsules, $R$, to be $\sim 2 \mu \mathrm{m}$, EQ 1 provides the number of capsules $N$ to be $8 \times 10^{10}$. This allows an estimate of the diffusion coefficient, $D$, of thymol blue through polystyrene of $5.5 \times 10^{-18} \mathrm{~m}^{2} \mathrm{~s}^{-1}$. This is a sensible order of magnitude for the diffusion of a molecule through a polymer.

\section{Table 1}

Table $1^{7} \mathrm{Li} \mathrm{NMR}$. lithium uptake from aqueous solution through the polystyrene shell into the lonic liquid core. intensity vs Time (Reference $1 \mathrm{M}$ LiCL $495 \pm 6$ ).

\begin{tabular}{|l|l|}
\hline $\begin{array}{l}\text { Time in solution } \\
\text { (hours) }\end{array}$ & Integrated ${ }^{7}$ Li intensity (a.u.) \\
\hline 0.5 & $471 \pm 6$ \\
\hline 2.5 & $482 \pm 6$ \\
\hline 73 & $488 \pm 6$ \\
\hline
\end{tabular}


For metal uptake experiments a $1 \mathrm{M}$ solution of $\mathrm{Li}^{+}$was prepared from its chlorinated salt. Samples of microcapsules were then exposed to the Lithium solution (SI S4). Lithium NMR was used to measure the lon uptake into capsules and this shows that Lithium ions are extracted from the salt solution very rapidly, within the 30 minutes of the first measurement. This implies that the ionic liquid capsules are easily saturated with lithium. (Figure 5) The average error is calculated from the

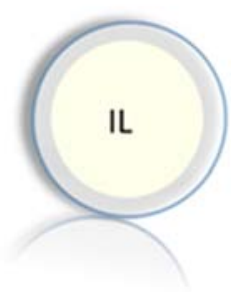

a

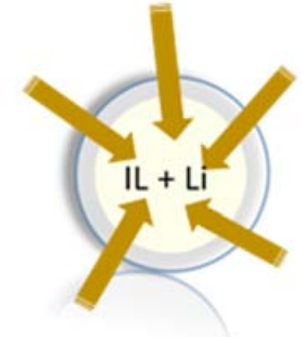

b

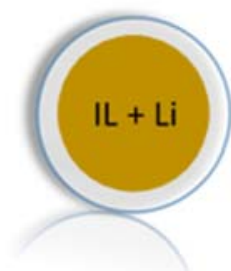

C

Figure 5 Schematic of lithium uptake experiments with ionic liquid core microcapsules a) IL core polystyrene shell $\quad$ b) uptake of metal through polymer shell. c) IL plus metal in core after metal uptake.

standard deviation of the repeats. (SI S7 metal ion uptake).

\section{CONCLUSION}

We have demonstrated the preparation and use of ionic liquid core polymer shell particles. The particles are easy to reproducibly prepare. Confining the ionic liquid in this way provides not just a practical way of using materials but also a neat discrete particle for fundamental study of ionic liquid behaviour in a confined space. We have shown the ability of the ionic liquid core to contain a model active compound, and to release it through the polymer membrane. The rate of release of a dye from intact capsules is shown to be determined by the diffusion of dye through the polymer shell. Despite diffusion coefficients as low as $10^{-18} \mathrm{~m}^{2} \mathrm{~s}^{1}$ the release from $\sim 2 \mu \mathrm{m}$ capsules occurs within a few hours. We also show the ability of metal ions to diffuse from a solution outside of the microcapsule and be concentrated within microcapsule (Figure 5).

In this work we show that ionic liquid core polymer shell materials can be made in significant quantities. Ionic liquid core polymer shell materials are likely to have several specific practical advantages: they are easy to filter/recover; they can act as distinct confined containers; their uniformity of size gives potential for use in liquid flow systems for printing of ionic liquid based einks or painting on to electrodes and surfaces. The ionic liquid core polymer shell particles can be tailored to allow diffusion out of or into the material as well as release at a specific temperature (melting point of polymer shell) or through mechanical destruction. Furthermore, ionic liquids can be chosen/tailored for their functionality, to extract or to release a target of interest, such as drug delivery or metal recovery. 


\section{ACKNOWLEDGEMENTS}

The authors are very grateful to the EPSRC Directed Assembly Network for a travel grant which helped to initiate this research. We also acknowledge many invaluable, insightful and entertaining discussions with Prof. K. R. Seddon. You are missed.

\section{Supporting information}

Details of materials, methods and characterisation.

\section{REFERENCES}

1 Walden, P. On the molecular size and electrical conductivity of some molten salts. Bull. Acad. Imper. Sci. (St. Petersburg) 1914, 8, 405-422.

https://scholar.google.com/scholar lookup?hl=en\&publication year=1914\&pages=405\&issn= 0098-2164\&author=P.+Walden

2 Sugden, S.; Wilkins, H. CLXVII.-The parachor and chemical constitution. Part XII. Fused metals and salts. J. Chem. Soc. 1929, 1291-1298. DOI: 10.1039/JR9290001291

3 Welton, T, Room-Temperature lonic Liquids. Solvents for Synthesis and Catalysis, Chem. Rev. 1999, 99, 2071-2083. DOI:10.1021/cr980032t

4 Earle, M. J.; Seddon K. R. Ionic liquids. Green solvents for the future. Pure Appl. Chem. 2000, 72, 1391-1398. DOI:10.1021/cr980032t

5 Watanabe, M.; Thomas, M. L.; Zhang, S.; Ueno, K.; Yasuda, T.; Dokko, K. Application of Ionic Liquids to Energy Storage and Conversion Materials and Devices. Chem. Rev., 2017, 117 (10), 719-7239. DOI: http://dx.doi.org/10.1351/pac200072071391

6 MacFarlane, D. R.; Tachikawa, N.; Forsyth, M.; Pringle, J. M.; Howlett, P. C.; Elliott, G. D.; Davis Jr. J. H.; Watanabe, M.; Simon P.; Angell, C. A. Energy applications of ionic liquids. Energy Environ. Sci., 2014, 7, 232-250. DOI: https://doi.org/10.1039/C3EE42099J

$7 \quad$ Armand, M.; Endres, F.; MacFarlane, D. R.; Ohno, H.; Scrosati, B. Ionic-liquid materials for the electrochemical challenges of the future. Nature Materials, 2009, 8, 621-629. DOI:

$10.1038 /$ nmat2448

8 Steinrück, H-P.; Wasserscheid, P. Ionic Liquids in Catalysis. Catal Lett., 2015, 145, pp 380397. DOI: 10.1007/s10562-014-1435-X

$9 \quad$ Blanchard, L. A.; Hancu, D.; Beckman, E. J.; Brennecke, J. F. Green processing using ionic liquids and $\mathrm{CO}_{2}$. Nature, 1999, 399. DOI: 10.1038/19887

10 Smiglak, M.; Pringle, J. M.; Lu, X.; Han, L.; Zhang, S.; Gao, H.; MacFarlane D. R.; Rogers, R. D. Ionic liquids for energy, materials, and medicine. Chem. Commun., 2014, 50, 9228-9250. DOI: 10.1039/C4CC02021A 
Vander Hoogerstraete, T.; Wellens, S.; Verachtert, K.; Binnemans, K.; Removal of transition metals from rare earths by solvent extraction with an undiluted phosphonium ionic liquid: separations relevant to rare-earth magnet recycling. Green Chem., 2013, 15, 919-927. DOI: 10.1039/c3gc40198g

Marrucho, I. M.; Branco, L. C.; Rebelo, L. P. N. Ionic Liquids in Pharmaceutical Applications Annual Review of Chemical and Biomolecular Engineering, 2014, 5, 527-546. DOI: https://doi.org/10.1146/annurev-chembioeng-060713-040024 Carter, E. B.; Culver, S. L.; Fox, P. A.; Goode, R. D.; Ntai, I.; Tickell, M. D.; Traylor, R. K.; Hoffman, N. W.; Davis Jr., J. H. Sweet success: Ionic liquids derived from non-nutritive sweeteners. Chem. Commun., 2004, 6, 630-631. DOI:10.1039/b313068a Gilmore, B. F.; Andrews, G. P.; Borberly, G.; Earle, M. J.; Gilea, M. A.; Gorman, S. P.; Lowry, A. F.; McLaughlin M.; Seddon, K. R. Enhanced antimicrobial activities of 1-alkyl-3-methyl imidazolium ionic liquids based on silver or copper containing anions. New J. Chem., 2013, 37, 873-876. DOI: 10.1039/C3NJ40759D

Toledo Hijo, A. A. C.; Maximo, G.J.; Costa, M. C.; Batista, E. A. C.; Meirelles, A. J. A. Applications of lonic Liquids in the Food and Bioproducts Industries. ACS Sustainable Chem. Eng., 2016, 4,5347-5369. DOI: 10.1021/acssuschemeng.6b00560

Shamshina, J. L.; Barber P. S.; Rogers. R. D. ionic liquids in drug delivery. Expert Opinion on Drug Delivery. 2013, 10. https://doi.org/10.1517/17425247.2013.808185 Gunaratne, H. Q. N.; Nockemann P.; Seddon, K. R. Pro-fragrant ionic liquids with stable hemiacetal motifs: water-triggered release of fragrances. Chem. Commun., 2015, 51, 44554457. DOI:10.1039/C5CC00099H Davis, J. H.; Forrester K. J.; Merrigan, T. Novel organic ionic liquids (OILs) incorporating cations derived from the antifungal drug miconazole. Tetrahedron Lett., 1998, 39, 8955-8958. DOI:https://doi.org/10.1016/S0040-4039(98)02070-X Shamshina, J. L.; Kelley, S. P.; Gurau G.; Rogers, R. D. Nature, 528,188-189. DOI:10.1038/528188a

Shadid, M.; Gurau, G.; Shamshin, J. L.; Chuang, B-C.; Hailu, S.; Guan, E.; Chowdhury, S. K.; Wu, J.-T.; Rizvi, S. A. A.; Griffin R. J.; Rogers, R. D. Sulfasalazine in ionic liquid form with improved solubility and exposure. Med. Chem. Commun., 2015, 6, 1837-1841.

DOI:10.1039/C5MD00290G

Banerjeea, A.; Ibsen, K.; Brown, T.; Chen, R.; Agatemor, C.; Mitragotri, S. Ionic liquids for oral insulin delivery. PNAS, June 25, 2018. 201722338.

DOl:www.pnas.org/cgi/doi/10.1073/pnas.1722338115

Banerjee, A.; Ibsen, K.; Iwao, Y.; Zakrewsky, M.; Mitragotri, S. Transdermal Protein Delivery Using Choline and Geranate (CAGE) Deep Eutectic Solvent. Adv. Healthcare Mater. 2017, 6, 1601411. DOI:10.1002/adhm.201601411 chemistry. Green Chem., 2016, 18, 105. DOI:10.1039/c5gc02277k 
McNeice, P.; Zhao, Y.; Wang, J.; Donnelly, G. F.; Marr, P.C. Low molecular weight gelators (LMWGs) for ionic liquids: the role of hydrogen bonding and sterics in the formation of stable low molecular weight ionic liquid gels. Green Chem., 2017, 19, 4690-4697.

DOI:10.1039/C7GC02053H

D'Anna, F.; Vitale, P.; Ferrante, F.; Marullo, S.; Noto, R. The Gelling Ability of Some Diimidazolium Salts: Effect of Isomeric Substitution of the Cation and Anion. ChemPlusChem, 2013, 78, 331-342. DOI:https://doi.org/10.1002/cplu.201300016

Wang, Y-M.; Ulrich, V.; Donnelly, G. F.; Lorenzini, F.; Marr, A. C.; Marr, P. C. A Recyclable Acidic Ionic Liquid Gel Catalyst for Dehydration: Comparison with an Analogous SILP Catalyst. ACS Sustainable Chem. Eng. 2015, 3, 5, 792-796. DOI: 10.1021/sc5008303

Bothwell, K. M.; Marr, P. C. Taming the Base Catalyzed Sol-Gel Reaction: Basic lonic Liquid Gels of $\mathrm{SiO}_{2}$ and $\mathrm{TiO}_{2}$. ACS Sustainable Chem. Eng., 2017, 5 (2), pp 1260-1263. DOI: 10.1021/acssuschemeng.6b02772

Marr, A. C.; Marr, P. C. Entrapping homogeneous catalysts by sol-gel methods: the bottom-up synthesis of catalysts that recycle and cascade. Dalton Trans., 2011, 40, 20-26. DOI:

\subsection{9/CODT00888E}

Atkin, R.; Warr, G.G. Structure in Confined Room-Temperature Ionic Liquids. J. Phys. Chem. C, 2007, 111, 5162-5168. DOI: 10.1021/jp067420g

Hayes, R.; Warr, G. G.; Atkin, R. Structure and Nanostructure in lonic Liquids. Chem. Rev., 2015, 115, 6357-6426. DOI: 10.1021/cr500411q

Liu, X-H.; Rebroš, M.; Dolejš, I.; Marr, A.C. Designing Ionic Liquids for the Extraction of Alcohols from Fermentation Broth: Phosphonium Alkanesulfonates, Solvents for Diol Extraction ACS Sustainable Chem. Eng., 2017, 5, 8260-8268. DOI: 10.1021/acssuschemeng.7b01934 Han, X.; Armstrong, D. W. Ionic Liquids in Separations. Acc. Chem. Res., 2007, 40 (11), 10791086. DOI: 10.1021/ar700044y

Durga, G.; Mishra, A. Ionic Liquids: Industrial Applications. encyclopedia of inorganic and bioinorganic chemistry. 2011, John Wiley \& Sons, Ltd. ISBN: 9781119951438. DOI: 10.1002/9781119951438 Karandikar, P.; Gupta, M. Fabrication of ionic liquid gel beads via sequential deposition. Thin Solid Films, 2017, 635, pp 17-22. DOI:https://doi.org/10.1016/j.tsf.2017.01.046 Marcilla, R.; Sanchez Paniagua, M.; Lopez-Ruiz, B.; Lopez-Cabarcos, E.; Ochoteco, E.; Grande, H.; Mecerreyes, D. Synthesis and characterization of new polymeric ionic liquid microgels. Journal of Polymer Science: Part A: Polymer Chemistry, 2006, 44, 3958-3965. DOI: https://doi.org/10.1002/pola.21483

Risch, S. J. Encapsulation: Overview of Uses and Techniques. ACS Symposium Series, 1995, 590, Chapter 1, 2-7. DOI: 10.1021/bk-1995-0590.ch001

Yow, H. N. Routh, A. F. Formation of liquid core-polymer shell microcapsules, Soft Matter, 2006, 2, 940-949. DOI: 10.1039/b606965g 
Keen, P. H. R.; Slater, N. K. H.; Routh, A. F. Encapsulation of amylase in colloidosomes. Langmuir, 2014, 30,1939-1948. DOI: 10.1021/la4047897 Sun, Q.; Du, Y.; Hall, E. A. H.; Luo, D.; Sukhorukov, G. B.; Routh, A. F. A novel fabrication method of gold coated colloidosomes and their potential application as targeted drug carriers. Soft Matter, 2018, 14, 2594-2603. DOI:10.1039/C7SM02485A

Yow, H. N.; Routh, A. F. Release Profiles of Encapsulated Actives from Colloidosome Microcapsules. Langmuir, 2009, 25, 159-166. DOI: 10.1021/la802711y

Zha, L.S.; Zhang, Y.; Yang, W.L.; Fu, S.K. Monodisperse Temperature-Sensitive Microcontainers. Advanced Materials, 2002. 14, 1090-1092. DOI: 10.1002/1521-

4095(20020805)14:15<1090::AID-ADMA1090>3.0.CO;2-6

Decher, G. Fuzzy Nanoassemblies:Toward Layered Polymeric Multicomposites. Science, 1997, 277. 1232-1237. DOI: 10.1126/science.277.5330.1232

Caruso, F.; Niikura, K.; Furlong, D. N.; Okahata, Y. Assembly of Alternating Polyelectrolyte and Protein Multilayer Films for Immunosensing. Langmuir, 1997. 13. 3427-3433. DOI:

10.1021/la9608223

Caruso, F.; Caruso, R. A.; Möhwald, H. Nanoengineering of Inorganic and Hybrid Hollow Spheres by Colloidal Templating. Science, 1998, 282. 1111-1114. DOI:

10.1126/science.282.5391.1111.

Donath, E.; Sukhorukov, G. B.; Caruso, F.; Davis, S. A.; Möhwald, H. Novel Hollow Polymer Shells by Colloid-Templated Assembly of Polyelectrolytes. Angew. Chem. Int. Ed. 1998, 37, 2201- 2205. DOI:https://doi.org/10.1002/(SICI)1521-3773(19980904)37:16<2201::AIDANIE2201>3.0.CO;2-E Dinsmore, A. D.; Hsu, M. F.; Nikolaides, M. G.; Marquez, M.; Bausch, A. R.; Weitz. D. A. Colloidosomes: Selectively Permeable Capsules Composed of Colloidal Particles. Science. 2002. 298. 1006-1009. DOI: 10.1126/science.1074868

Velev, O. D.; Furusawa, K.; Nagayama, K. Assembly of Latex Particles by using Emulsion Droplets as Templates. 1. Microstructured Hollow Spheres. Langmuir, 1996, 12, 2374-2384. DOI: 10.1021/la9506786

Velev, O. D.; Furusawa, K.; Nagayama, K. Assembly of Latex Particles by Using Emulsion Droplets as Templates. 2. Ball-like and Composite Aggregates. Langmuir, 1996, 12, 2385-2391. DOI: 10.1021/la950679y

Velev, O. D.; Nagayama, K. Assembly of Latex Particles by Using Emulsion Droplets. 3. Reverse (Water in Oil) System. Langmuir, 1997, 13, 1856-1859. DOI: 10.1021/la960652u 


\section{"For Table of Contents Use Only."}

\section{SYNOPSIS}

Ionic liquid contained within discrete self-organized polymer spheres (microcapsules). A Low temp, high yielding, one-pot route to polymer membrane ionic liquid core microcapsules for sustainable applications.

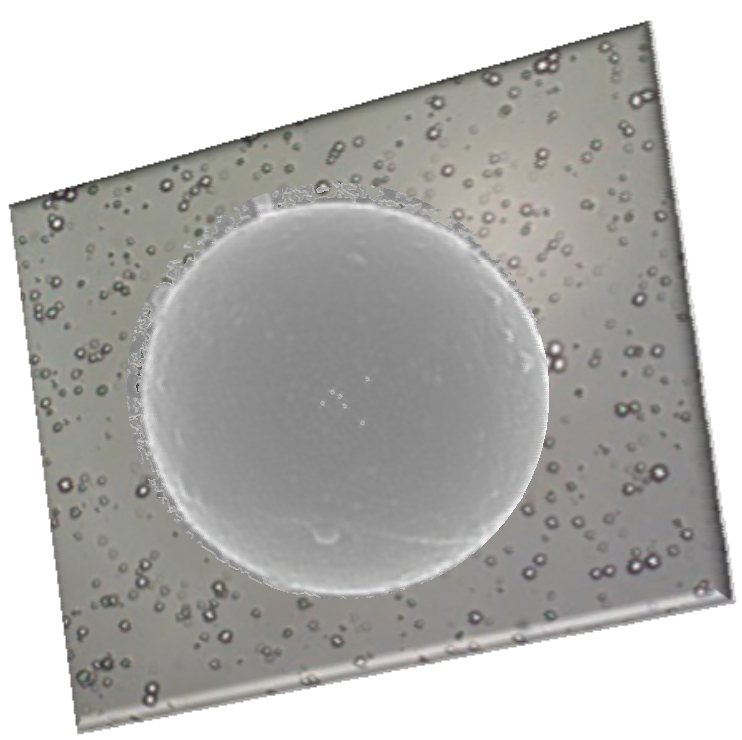

